\title{
Examining the Social Outcomes from Urban Transport Infrastructure: Long-Term Consequences of Spatial Changes and Varied Interests at Multiple Levels
}

\author{
Juhyun Lee $^{1, * \mathbb{C}}$, Jos Arts ${ }^{1}{ }^{\mathbb{D}}$, Frank Vanclay ${ }^{1} \mathbb{D}$ and John Ward ${ }^{2}$ \\ 1 Faculty of Spatial Science, University of Groningen, 9700 AV Groningen, The Netherlands; \\ jos.arts@rug.nl (J.A.); frank.vanclay@rug.nl (F.V.) \\ 2 The Bartlett School of Planning, University College London, London WC1H 0NN, UK; eric.ward@ucl.ac.uk \\ * Correspondence: juhyun.lee@rug.nl
}

Received: 26 June 2020; Accepted: 20 July 2020; Published: 22 July 2020

check for updates

\begin{abstract}
This paper investigates how social outcomes from urban transport projects typically play out by reflecting on multi-scale spatial changes induced by projects over time, and the extent to which such changes meet varied interests in project outcomes. We use a multi-methods case study approach using two exemplars, a metro project in London and Seoul, which established extensive public transport networks to support urban growth. Our study highlighted that urban transport network expansion does not always enhance life opportunities for all due to intermediate and cumulative impacts of spatial changes induced by projects. Immediate benefits such as enhanced accessibility were often undermined by long-term consequences of incremental spatial changes at local scales. This study also indicated that differential patterns of spatial changes around nodes between centre and periphery could be attributed to multiple negative impacts on people living in the most deprived areas. To enhance social outcomes, we suggest an integrated approach to urban transport and spatial development that focuses on scale and temporal dimensions of spatial transformation enacted by projects. In conclusion, achieving sustainable and equitable effects from urban transport infrastructure requires careful examination of broader societal consequences of long-term spatial changes and locational contexts, especially function and socio-economic conditions.
\end{abstract}

Keywords: urban spatial transformation; public transport; land usetransport integration; spatial equity; integrated planning; megacities; megaprojects; sustainable transport

\section{Introduction}

Urban transport infrastructure development is often seen as a critical catalyst in the process of nation building and in urban and regional development, providing step changes in connectivity for the development of society and the economy [1,2]. Such development is emphasized as a means of promoting economic growth, both in the West and increasingly in Asia [3]. Many megacities across the globe make huge investment in mega urban transport infrastructure. Arguably, an overemphasis has been placed on the economic goal of infrastructure development at a macro level (e.g., national and metropolitan level), while the varied interests in such projects and social outcomes over time and space have been under-assessed in planning and decision making, especially at a local level of neighbourhoods [4-6].

Rodrigue [7] and Lee [8] noted that there is only limited investigation of the socio-spatial implications of urban transport infrastructure development, often via simplistic forms of distributional analysis of travel time gains. It was argued that infrastructure development has a strong influence on urban spatial structure and form, and that the long-term consequences of spatial changes enacted at 
multiple scales also need to be considered in order to understand the outcomes of transport development. Several authors (e.g., [9]) have emphasized that these consequences affect various socio-economic indicators, and that urban infrastructure development does not always improve wellbeing, as it often fails to meet many of the varied interests over time and space $[10,11]$. In practice, the relation between transport development and urban form has been much discussed [12,13]. However, there has only been limited research on how the long-term spatial changes at macro and micro scales influence the social outcomes of urban infrastructure development over time and space [14,15]. Moreover, the outcomes are rarely examined in terms of the specific context of each setting, even though the spatial changes and long-term consequences are much influenced by the context [16,17]. In practice, the long-term social outcomes of urban infrastructure development are rarely assessed (ex-ante) or evaluated (ex post), especially in terms of how the respective interests are or will be affected by the multi-scale spatial changes generated by the projects.

The purpose of this paper is to analyse how the social outcomes from urban transport infrastructure projects typically play out, given the long-term spatial changes and the varied interests in the outcomes of projects. We do this by examining the long-term consequences at multiple scales of the spatial changes facilitated by two exemplars, metro projects in two metropolises, London (UK) and Seoul (Korea). These two cities are examples of metropolitan cities with a population of approximately 10 million that have established extensive public urban transport networks (i.e., metro) in response to their need for sustaining economic growth and improving accessibility to opportunities. We consider the respective interests in the two projects from the perspectives of transport and urban spatial development at multiple levels (i.e., national, city, neighbourhood levels), and we reflect on the extent to which these interests were met by project outcomes. Using a case study approach [18], we investigate the social outcomes of the projects by considering the specific context of each case.

By 'social outcomes', we mean the societal consequences that actually occur at multiple scales over time as a result of the implementation of urban infrastructure projects, as well as the spatial transformation enacted by such projects. The outcomes include, for example, enhanced mobility and accessibility, improved wellbeing, and increased livelihood opportunities for urban populations. Ultimately, we seek to contribute to planning practice by addressing how the ultimate benefits of transport development are shaped by multi-scale spatial changes over time, and by the context. Furthermore, we discuss how integrated approaches to transport and urban spatial development at macro and micro scale contribute to social outcomes at all levels.

\section{Urban Infrastructure Development and Spatial Changes at Multiple Scales}

Urban infrastructure is a critical agent of change in the current era of globalisation and the market-driven economy [2]. Infrastructure development plays a key role in increasing the competitiveness of cities and the socio-economic wellbeing of urban populations [1]. City rankings, such as the Global City Power Index [19], often include infrastructure as a key element in their assessments. The experience of urban infrastructure investment suggests there is an intertwined relationship between infrastructure development and urban growth [20], and possibly decline [21]. Infrastructure plays a critical role in the construction and development of urban territory, especially in the formation of networks and linkages (of all kinds), which create connections and interdependencies within and between places and their users, and designate the form and function of the space in physical and socio-economic terms [22-24].

Urban infrastructure facilitates spatial changes at a macro scale (i.e., change in spatial structure of a city) and a micro scale (i.e., change in land use and physical environment in a local neighbourhood) as it interacts with urban (re)development processes at city and local neighbourhood levels $[7,20,25,26]$. At the macro scale, transport infrastructure can enhance connectivity to major nodes, facilitating spatial (re)organisation, e.g., the concentration of social and economic activities in the core of cities $[7,27]$ At the micro scale, an increase in urban transport capacity could facilitate high-density, mixed-use development at the nodes, enhancing attractiveness of a location for certain land uses $[28,29]$. Urban 
infrastructure development not only connects areas, but also causes spatial severance, fragmentation, and the physical displacement of communities [6,30]. These spatial changes often occur over the long term and are cumulative in nature [15].

Various authors have argued that the spatial changes facilitated by urban infrastructure influence the socio-economic wellbeing of society (e.g., accessibility and quality of life of urban population) at macro and micro levels (e.g., [31,32]). Macro-scale spatial transformation induced by urban infrastructure (e.g., a city's polycentric spatial structure) contributes to increasing economic production and an increased supply of labour [1]. Local-scale changes arising from infrastructure development influence the way people live, work, and play, which affects the overall quality of everyday life of local communities $[15,30]$. A few scholars $[14,33]$ emphasised that transport development should enhance people's life opportunities by facilitating improvement in accessibility for all. However, in practice, long-term changes related to infrastructure projects often facilitate a spatially-differentiated distribution of benefits over time and gentrification effects, gradually affecting the social equity of cities [34,35], e.g., spatial mismatches between low income groups and job opportunities [36].

\section{Varied Interests and Long-Term Consequences at Multiple Levels}

The long-term consequences of urban infrastructure development projects are closely related to urban (re)development policies [10,37]. The consequences are complex, and are influenced by the interactions between various actors who have varied interests $[38,39]$. The diversity and complexity of the interests vary across urban areas and by scale [40]. Giddens [41] emphasized that urban transformation should be examined at macro and micro levels. At the macro perspective, infrastructure development is viewed as a means to achieve the macro-economic goals of cities and regions, and is considered to be a catalyst for spatial development $[2,11]$. The micro perspective relates to how infrastructure projects interface with the spaces in which everyday life occurs [42], e.g., enhancing access to local infrastructure and services being important to improve the wellbeing of local communities [3]. Madanipour [42] argued that interests from macro and micro perspective need to be met by the spatial transformation that is triggered by urban development projects. Understanding the long-term consequences of infrastructure development requires investigating the processes of spatial change in conjunction with considering the interests at the multiple levels [41].

In practice, decision making has often been framed by politics that reflect macro-scale economic goals, thus influencing the long-term consequences likely to arise from urban development projects $[2,43]$. With political and economic interests typically being dominant in the decision-making process, the high-level goals (i.e., increasing access to economic centres of cities) are often prioritized over lower-level goals through top-down planning process [44,45]. Moreover, despite claims that transport development needs to address broader long-term goals of urban development by an integrated approach [46], transport planning and spatial planning still occur in separate silos, and address different priorities $[47,48]$. In fact, how the multi-scale spatial changes induced by urban transport projects actually influence the project outcomes is rarely considered [14,49]. Rydin [50] argued that the consequences are not addressed with respect to the varying socio-economic needs of local neighbourhoods across cities. In our paper, we address this lack of consideration of the consequences of the multi-scale spatial changes that are triggered by mega urban infrastructure projects and how they affect the varied interests by developing a conceptual framework for examining the social outcomes of urban infrastructure development projects.

\section{A Framework to Examine the Social Outcomes from Urban Infrastructure Development}

Although we have provided a literature review above, in order to develop our framework, here we specifically focus on how the social outcomes from urban transport infrastructure projects typically play out, given the long-term spatial changes and varied interests in projects. First, urban transport development creates winners and losers, especially from the standpoints of mobility, accessibility, and environmental and economic concerns [9]. Second, by overlooking the long-term 
social consequences of transport decision making at every level of the project process, infrastructure development undermines the quality of life and wellbeing of urban populations [15]. Third, the outcomes of urban spatial development should be understood by considering the diverse needs of the urban population who live and work in the city $[39,51]$. Fourth, there is need for comprehensive investigation of the diversity of contextual circumstances in order to understand the long-term outcomes of urban projects [16]. Therefore, the ultimate outcomes of urban infrastructure development need to be evaluated by examining the extent to which the long-term consequences of spatial changes associated with infrastructure development meet the varied interests over the long term.

We present a conceptual framework to illustrate the social outcomes of urban infrastructure development (see Figure 1). In this framework, the long-term consequences of spatial changes at macro and micro scales induced by urban transport infrastructure projects are related to the multiple interests in urban transformation at macro and micro levels. Macro-scale change includes change in spatial structure of a city (e.g., creation of new urban centre), and micro-scale change comprises change in land use (e.g., change in the density of development around transport nodes) and physical environment (e.g., change in functionality of road layout). The long-term consequences refer to changes in quality of everyday life and accessibility to jobs and services. Multiple interests refer to the varied goals of the different stakeholders in a project from transport and spatial development perspectives and at macro and micro levels (e.g., nation, metropolitan and local neighbourhood levels). The figure illustrates that high-level social outcomes are delivered when the long-term consequences arising from spatial changes at macro and micro scales together contribute to meeting the varied interests in a project over a longer period. Below, we apply this model to specific cases of urban development in London and Seoul.

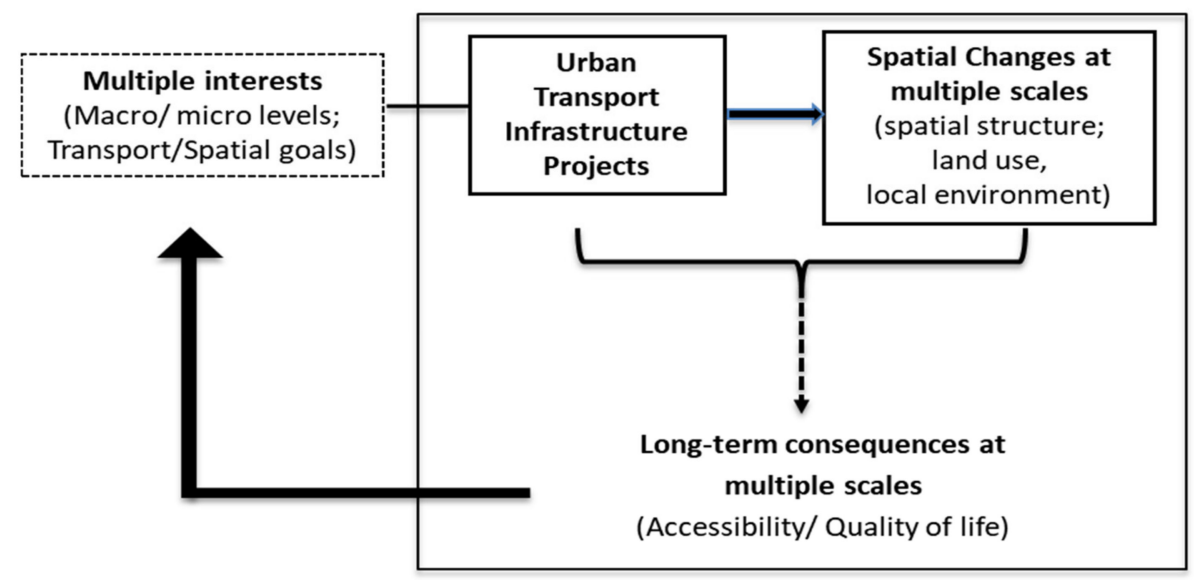

Social Outcomes from Urban Transport Infrastructure Development

Figure 1. An indicative conceptualisation of social outcomes from urban transport development.

\section{Methodology}

To examine the social outcomes from infrastructure development projects, we used two exemplars of urban transport infrastructure projects in megacities: the Jubilee Line Extension (JLE) in London; and the Second Phase Subway Development in Seoul (Second Phase). We used a multi-case study approach [18] to investigate how social outcomes from urban transport development projects play out over time in given contextual circumstances.

London and Seoul are both examples of large metropolitan cities (with a population of approximately 10 million) that have established extensive urban transport networks (metro lines) in response to a perceived critical need to (re)develop the metropolitan area because of a growing economy and population $[52,53]$. With continually expanding metro networks, in both cities the metro became a main transport mode for the urban population $[54,55]$. The JLE and Second Phase were selected because both projects started operation around 2000 and both created spatial changes at metropolitan and neighbourhood scales, influencing the socio-economic wellbeing of the whole urban 
population [52,56-58]. However, these two cities differ in some aspects, such as their pattern and stage of urban development.

As indicated in Figure 1, the mid- to long-term consequences (i.e., approximately 15 years) of the two projects were evaluated in relation to spatial changes and the varied interests in the projects at multiple levels. Given the complexity of evaluating outcomes [59], we used multiple methods in a pragmatic and contextualised approach [60] to investigate each exemplar. Our research included an analysis of primary source documents (e.g., key project documents); secondary sources (e.g., news reports, journal articles); official data (e.g., census data); in-depth interviews with experts and key stakeholders; semi-structured interviews with residents; and onsite observation.

Using multiple methods, data about interests and outcomes were collected and analysed at multiple levels and across the different areas (i.e., local neighbourhoods) in each city. To understand the interests related to the projects, although arguably conceptually different, we used stated project goals as a proxy for the interests of certain stakeholders. To understand the outcomes, quantitative and qualitative measures were used to investigate the multi-scale spatial changes (i.e., change in spatial structure, land use, and physical environment) and long-term consequences (i.e., accessibility to opportunities and quality of life at multiple scales) in line with the conceptual framework in Figure 1. As not all the relevant concepts are readily measurable, some proxy measures were used (see Table 1).

Table 1. Criteria and indicative measures used to examine outcomes from infrastructure development.

\begin{tabular}{|c|c|c|c|c|}
\hline \multirow{2}{*}{ Scale } & \multicolumn{2}{|c|}{ Urban Spatial Changes } & \multicolumn{2}{|c|}{ Long-Term Consequences Associated with Spatial Changes } \\
\hline & Construct & Example Proxy Measures & Construct & Example Proxy Measures \\
\hline Macro & $\begin{array}{l}\text { Change in spatial } \\
\text { structure of cities }\end{array}$ & $\begin{array}{l}\text { number, size and type of } \\
\text { transport/regeneration projects } \\
\text { implemented, and employment } \\
\text { density in (newly created) } \\
\text { centres (e.g., within } 500 \mathrm{~m} \\
\text { from stations) }\end{array}$ & $\begin{array}{l}\text { Accessibility and } \\
\text { quality of life at } \\
\text { macro scale }\end{array}$ & $\begin{array}{l}\text { - } \quad \begin{array}{l}\text { number and } \% \text { of population } \\
\text { commuting over } 60 \text { mins }\end{array} \\
\text { - } \quad \text { number and \% of population with } \\
\text { access to subway within } 500 \mathrm{~m}\end{array}$ \\
\hline Micro & $\begin{array}{l}\text { Change in land use } \\
\text { and physical } \\
\text { environment }\end{array}$ & 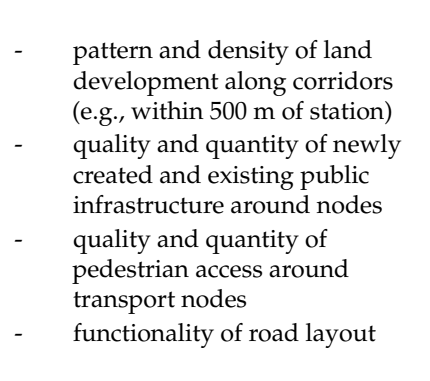 & $\begin{array}{l}\text { Accessibility and } \\
\text { quality of life at } \\
\text { micro scale }\end{array}$ & $\begin{array}{l}\text { - local safety; range of } \\
\text { local amenities } \\
\text { accessibility to jobs and services, } \\
\text { and public transport (e.g., no. of } \\
\text { jobs within } 30 \text { min journey time; } \\
\text { commuting time) } \\
\text { differential outcomes among local } \\
\text { neighbourhoods (e.g., \% of } \\
\text { population commuting less than } \\
60 \text { min by local district; } \% \text { of area } \\
\text { without subway within } 500 \mathrm{~m} \text { by } \\
\text { local district) }\end{array}$ \\
\hline
\end{tabular}

To identify the interests and understand the context of each case, we examined all relevant documents, including official project documents, White Papers, territorial policy, transport plans at different scales, strategic urban plans, and local development plans and policies. To understand the outcomes of each case, we examined impact assessment reports, results of local surveys, historic maps, and empirical studies on the spatial changes and long-term consequences of each project. Official data and surveys were also examined, including journey-to-work time, public transport accessibility data, and annual business surveys. Income data and the deprivation index across cities provided information about differential outcomes between and within neighbourhoods. Various time periods and scales of data were used to identify the changes taking place in London and Seoul over time and space. Onsite observation was also undertaken, especially to validate information relating to ease of access, and quality of public space in proximity to nodes.

Some 22 in-depth interviews were conducted in 2018 with a range of key stakeholders (16 in Seoul and 6 in London). They included people working for government or policy institutes (urban and transport development) at national, metropolitan, or local neighbourhood levels, on matters concerning transport, territorial (spatial) planning, project development. Interviewees were selected according to their role in the planning process (i.e., key decision makers or technical planners in spatial and/or 
transport planning involved in the actual projects). Interviewees were identified through snowballing. Collection of interview data ceased when recurring viewpoints occurred with additional interviews and saturation was achieved [61]. The interviews were structured along the lines of the conceptual framework (Figure 1), identifying policy goals and key interests in the project at multiple levels, and views on spatial changes and associated long-term consequences. The interviewees were asked which interests were prioritized during planning and implementation of the project. Interviewees were also asked to give their opinions on the extent to which the project met the various interests and to identify any other factors that affected the project process and outcomes. The interviews were done in a manner consistent with ethical social research [62].

In London, in addition to the in-depth interviews with key stakeholders, 29 semi-structured interviews were conducted with Canning Town residents in July 2016. These interviews investigated the spatially-differentiated outcomes and interests among the different social groups. Canning Town was one of the most deprived neighbourhoods along the JLE [63], even though regeneration schemes had been implemented there since the JLE opened. Questions were structured around three topics: the life pattern of these residents; the positive and negative changes experienced; and the impacts of these changes on their quality of life.

The long-term consequences of the projects were evaluated by analysing all data collected. The transcripts of interviews were coded and analysed using ATLAS.ti. The analysis was based around the following specific questions: (1) to what extent did the spatial transformation triggered by the project bring positive consequences at the local scale as well as the macro scale? (2) to what extent were the varied interests of the population (at neighbourhood and metropolitan and national levels) addressed in the long term? (3) to what extent were the interests of different parts of the cities (i.e., centre and periphery, most deprived and least deprived) addressed in a fair manner?

\section{Exemplar 1: Jubilee Line Extension in London}

\subsection{Background}

London experienced much urban expansion and transformation in the 20th century [64]. This transformation was largely possible because of its network of metropolitan railways, the backbone of which was developed between 1850 and 1930 [32]. London's expansion was not without some setbacks. Economic decline following World War II up until the early 1990s led to net out-migration [64]. The London Docklands, in east London, was particularly affected by this decline. Traditionally an important port and warehousing district, containerisation and the shift to large freight ships diminished its status. With poor land transport links to London central city, the Docklands was effectively cut off and its local economy floundered, leading to widespread deprivation [57]. In the 1980s, the national government, Greater London Council, and five local borough governments in the Docklands put much effort into regenerating the area. One important project was the Docklands Light Rail, which was opened in 1987 to improve access and provide the transport infrastructure necessary to stimulate development in east London. Economic and population growth across London in the 1990s led to discussion about the need for new economic centres and to extend and enhance London's mass transport system.

The Jubilee Line Extension (JLE) was opened in 1999 to create better links between London city centre, Thames South Bank, Canary Wharf and Stratford (see Figure 2). At $16 \mathrm{~km}$ in length, it passes through six boroughs. The line was initially conceived by the developers of Canary Wharf as a way to facilitate its further development as a major financial and commercial centre. 


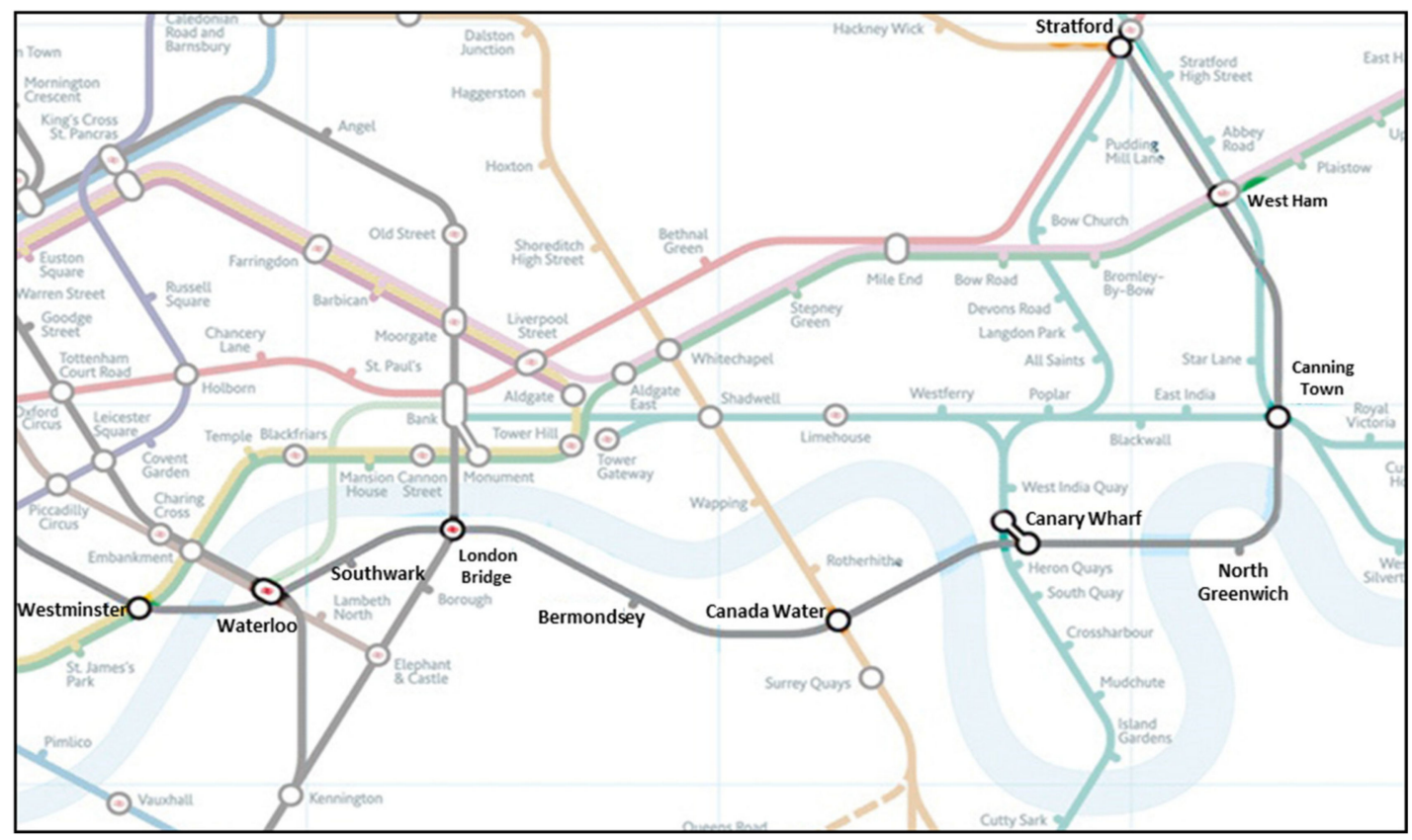

Figure 2. The Jubilee Line Extension in east London (note: the JLE is the dark grey line running from Westminster to Stratford) (source: adapted from london-tube.com [65]).

\subsection{Key Interests Related to the Jubilee Line Extension at Multiple Levels}

The analysis of documents and interviews enabled the varying interests in the outcomes of the JLE to be identified, and were affected by level (e.g., national, city, and neighbourhood) and sector (e.g., transport and urban development). The principal transport planners for the JLE project (whom we interviewed) emphasised that the main intention of the decision makers at the national level was for the JLE to contribute to sustaining London's dominant position as a financial centre by facilitating the further development of Canary Wharf. The top priority of central government and the owner of Canary Wharf was to increase accessibility to Canary Wharf by ensuring there was a direct link between it and the city centre, as well as to the mainline rail terminals (e.g., Waterloo) [66]. As indicated by our interviews with local planning officers and our document analysis, the key interests at the city level were to reduce development pressure in the city centre by encouraging development of housing and office projects in east and south London; and provide better access to the Underground, especially for people who were previously underserviced [52].

At the local level, we identified that the major interests were increased accessibility to various destinations and job creation. A transport planner we interviewed indicated that local authorities had different levels of interest in the secondary development effects (i.e., housing, office, commercial development) around the new and redeveloped stations built for the JLE due to the differing priorities of the local authorities. Some aspired to have high-density mixed-use development, which would flow from the development of stations, while others (e.g., some boroughs in south London, such as Southwark) were not interested in such development [52,67]. Furthermore, in the interviews with local residents in Canning Town, different interests in urban regeneration associated with JLE were identified among different groups of people. Some anticipated a better living environment and business opportunities, while others were concerned that the development opportunities would be inconsistent with the needs of local people in their neighbourhood. Table 2 presents a summary of the interests identified in our study. 
Table 2. Interests related to the outcomes of the Jubilee Line Extension at multiple levels.

\begin{tabular}{ccc}
\hline Level & \multicolumn{1}{c}{$\begin{array}{c}\text { Interests Related to } \\
\text { Transport Development }\end{array}$} & Interests Related to Urban Development \\
\hline $\begin{array}{c}\text { National and } \\
\text { regional levels }\end{array}$ & $\begin{array}{c}\text { Increase access to a newly developed } \\
\text { economic hub from central hubs and } \\
\text { wider areas }\end{array}$ & $\begin{array}{c}\text { Support continuation of investment and } \\
\text { economic growth by establishing a } \\
\text { financial centre }\end{array}$ \\
\hline City level & $\begin{array}{c}\text { Give better access to Underground services } \\
\text { for a wider area (i.e., east and southeast } \\
\text { London), and relieve traffic and congestion }\end{array}$ & $\begin{array}{c}\text { Support development and enhance } \\
\text { regeneration along the routes, and reduce } \\
\text { development pressure in the city centre }\end{array}$ \\
\hline $\begin{array}{c}\text { Neighbourhood } \\
\text { level }\end{array}$ & $\begin{array}{c}\text { Increase accessibility to jobs and services in } \\
\text { the centre and local areas (the aspiration } \\
\text { since 1980s) }\end{array}$ & $\begin{array}{c}\text { Job creation and better business } \\
\text { opportunities, provide modern facilities } \\
\text { and housing, and develop public services }\end{array}$ \\
\hline
\end{tabular}

\subsection{Spatial Changes and Associated Long-Term Consequences at Macro and Micro Scales}

Our research revealed that the macro-scale spatial changes facilitated by the JLE included a transformation of the Docklands into a major commercial centre in competition with the traditional commercial centre of London, thereby contributing to changing the overall spatial structure of London, arguably from a monocentric to polycentric form [27]. Development at principal nodes led to demand for more transport, which in turn produced increasing demand for more development. As seen in Figure 3, Canary Wharf became the key centre of commerce and business in London, with its growth in employment outperforming most of the rest of London since the JLE opened $[52,68]$. The JLE also unlocked the development potential of a number of former industrial sites in east London, such as Canada Water and North Greenwich [67]. Major projects that became possible (or at least, facilitated) by the JLE include the Millennium Dome, regeneration of Stratford and Olympic Park, and the Greenwich Peninsular redevelopment project. The JLE was also associated with enhancement of London's South Bank, a major centre of entertainment. As a result of all this development, the general conception of London's inner boundary has shifted towards the east [57].

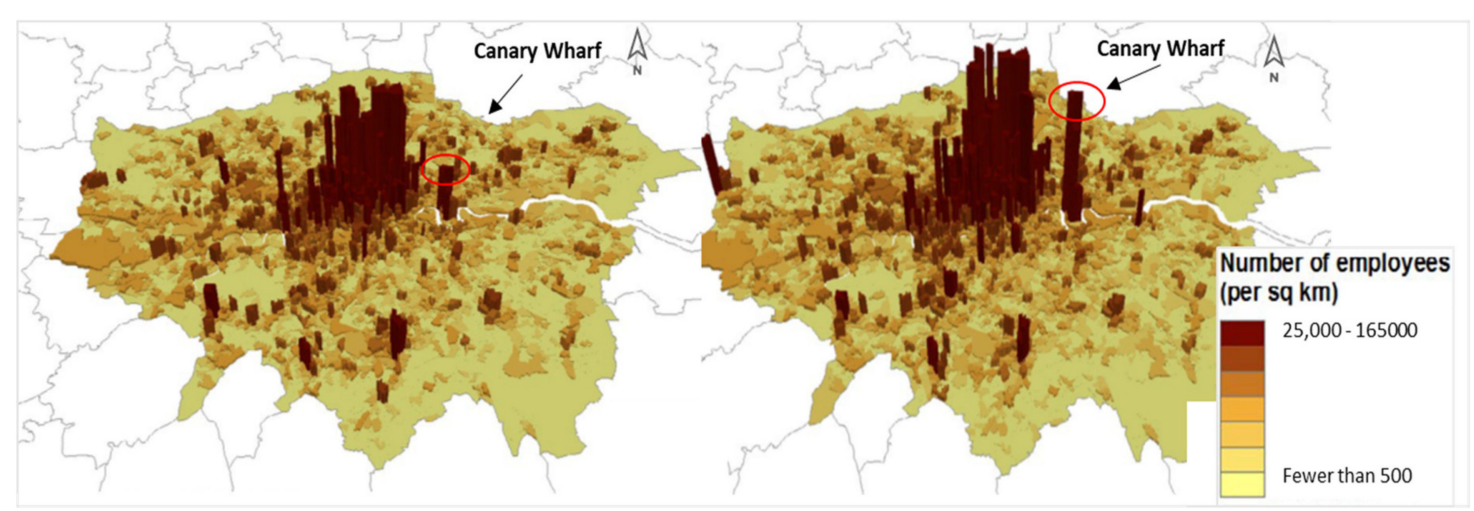

Figure 3. Numbers of employees per $\mathrm{km}^{2}$ in London in 2003 (left) and 2014 (right) (source: adapted from GLA [68] (p.65)).

The JLE led to land-use changes around the stations along its route $[69,70]$, especially in the catchments outside central London (i.e., Bermondsey and the stations to the east) [71]. The Canary Wharf development and related projects led to multi-nodal spatial concentration of economic and social activity. A development impact study [67] and our interviewees indicated that development activity has been strong in most areas served by the JLE. The major interchange stations, such as Waterloo and London Bridge, became renewed transport hubs, providing an interchange with National Rail services [66]. They experienced mixed-use development of higher density, including commercial development as well as redeveloped public space [72]. Around some residential towns, such as Canning Town and West Ham, regeneration projects with a high portion of residential development occurred [52]. The 
interviews with local planners indicated that this involved re-designing underutilised sites. New local roads and pedestrian routes between stations and their catchments were gradually developed.

Our study showed that along with changes in spatial structure (macro scale), the JLE increased accessibility to jobs and to major cultural and commercial facilities around the principal nodes, contributing to economic growth at the metropolitan and national scales, but not necessarily in all localities [67,71]. This increased accessibility brought about further development at the major nodes. For example, even London's CrossRail project is intended to support the ongoing development of Canary Wharf [73]. Moreover, the creation of interchanges and improvement of public facilities resulted in a vibrant socio-economic environment around the principal nodes, benefiting much of London's population [72]. As a result of the 2012 Olympics, and following the redevelopment of its station, Stratford has become a commercial and transit hub at a regional level, contributing to the ongoing spatial transformation of the area [74].

At the local scale, according to the analysis of the official data and interviews, the JLE and the change in land use and local environments in close proximity to stations contributed to bringing positive changes to neighbourhoods, albeit in unique ways, depending upon the particulars of each location. The local population benefited from enhanced accessibility to jobs in the commercial centres, as well as from increasing commercial services and socio-economic activities near the intermodal interchange stations $[52,55,72]$. Moreover, the interviews with people in Canning Town and with local officers indicated that, with the redevelopment of the stations, there were improvements in safety and in the local built environment, especially in terms of improvement of facilities and creation of modern public spaces. However, some negative consequences were also identified [72], for instance, the majority of interviewees from Canning Town complained that a high-density mixed-use development project at the station impeded their access to the station and that the redeveloped public space was of lower quality than before. Some households were displaced by new housing developments in the vicinity of their station [8]. Moreover, the local planning officers pointed out that spatial changes concentrated around stations negatively influenced community cohesion among local communities due to disparity in the quality of the built environment between the new developments around the nodes and the rest of catchment areas.

Spatially differentiated outcomes were noted in terms of the varying levels of benefits from the JLE occurring between and within neighbourhoods, indicating spatial and social disparity. Official statistics [75] - e.g., the numbers of workplaces and services that can be reached from stations within a specified time, and public transport accessibility level (PTAL) - and our interviews showed that the three neighbourhoods with the greatest income deprivation (North Greenwich, West Ham and Canning Town) [63] had less regeneration effects than other neighbourhoods and had lower accessibility to jobs and services. Differential outcomes (in terms of land use, quality of the built environment, and accessibility to public transport) were observed within some catchment areas (notably Canning Town), particularly between the station area and the rest of the neighbourhood [76]. Our analysis of interviews and statistical data [63] indicated that the most disadvantaged areas in Canning Town experienced only minimal benefits, because people had limited public transport or local amenities. The majority of people living in these areas experienced poor accessibility to public transportation [77], while the least deprived lived in close proximity to the Canning Town station.

\subsection{Analysis of Issues Related to the Social Outcomes from the Jubilee Line Extension}

Our analysis of key documents, official statistics, and interviews illustrate that the JLE delivered outcomes that largely met the macro-level economic goal. The JLE contributed to increasing the competitiveness of the metropolitan area as a driver of economic growth of the nation by increasing accessibility to the new financial centre (Canary Wharf) and other key destinations. It also met the goal of bringing regeneration effects along the route by unlocking the development potential of south and east London and by increasing socio-economic vibrancy along the transport corridor. This occurred gradually as new spatial development increased demand for transport, which in turn led to further 
development. As such, the JLE met the objectives of enhancing access to the new economic hub and better access to the Underground, especially for those living further away.

At the local level, however, it is not clear whether the JLE and the associated spatial changes brought about net improvement in the quality of life in all local neighbourhoods, or met the varied respective interests. Our analysis indicated that neighbourhoods in east London (e.g., Canning Town) experienced poor accessibility to opportunities and public transport, because of the local consequences of the regeneration projects (e.g., poorly integrated designs blocking public passages and poor quality of the regenerated public space adjacent to nodes). The regeneration projects hardly addressed the interests of some neighbourhoods for improved social infrastructure, as they mainly resulted in high-density mixed-use development. Moreover, our research identified that local neighbourhoods benefited from reduced journey time once the project opened. However, there was spatial and social differentiation in the benefits over time. This study showed that the differential levels of accessibility to infrastructure were exacerbated by regeneration projects targeted only to specific locations (e.g., areas adjacent to transport nodes), and by the loss of local amenities in locations at the edge of catchment areas. Such consequences are related to multiple negative impacts on accessibility for people living in the most deprived areas within neighbourhoods, negatively influencing social cohesion. Overall, it is questionable whether the JLE brought about positive net change in the wellbeing of all local communities over time, or in meeting the interests of all stakeholders in a balanced manner.

As confirmed by the interviews with principal transport planners at national and metropolitan levels, key decision makers were mainly concerned about the cost efficiency of development and quickly increasing connectivity to Canary Wharf and between the principal nodes. The central government took control of local planning, and the differing priorities and concerns of the various boroughs were not taken into consideration, even though some local authorities including those in south London expressed concerns about the negative consequences their neighbourhoods would experience. In practice, the primary concern of the planners was to enhance the mobility of the urban population rather than to increase overall accessibility to opportunities and connectivity to stations. Interestingly, the planner at one local borough suggested that the key objective of the regeneration projects was not increasing overall social wellbeing, but increasing density through more private residential housing.

\section{Exemplar 2: The Second Phase Subway Development in Seoul}

\subsection{Background}

By 1990, Seoul had become a global metropolis, with a population reaching 10 million, having gone through high economic growth and rapid urbanisation since the end of the Korean War in 1953 [54]. During recent decades, the city has built large-scale urban infrastructure at a rapid rate, resulting in a continuously-rising population and traffic congestion, along with economic growth [54]. The city centre experienced rapid development and increasing employment. In the 1970s, the metropolitan government decided to redistribute key urban functions and population to Gangnam, which was previously a peripheral area south of the Han River and from which it gets its name (Gang = river, $\mathrm{Nam}=$ south). The increasing need for subway development was also considered, especially because of road congestion and to support the shift to a polycentric city structure [78]. During the First Phase of subway development, from 1970 to 1985, lines 1, 2, 3, and 4 were built, $116 \mathrm{~km}$ in total. These lines all pass through the commercial centre in the north and the newly-created sub-centres (Yeouido and Youngdong) in the south (see Figure 4).

In the 1990s, the Second Phase Subway Development (lines 5 to 8 ) was constructed to support the continually-increasing employment growth concentrated in the centres, to increase accessibility to jobs and services from wider areas, and to support city expansion. The Second Phase extended the subway network by $145 \mathrm{~km}$, adding 148 stations. Taking only 10 years to complete, it created rapid and major changes to the city structure and contributed to urban expansion [79]. 


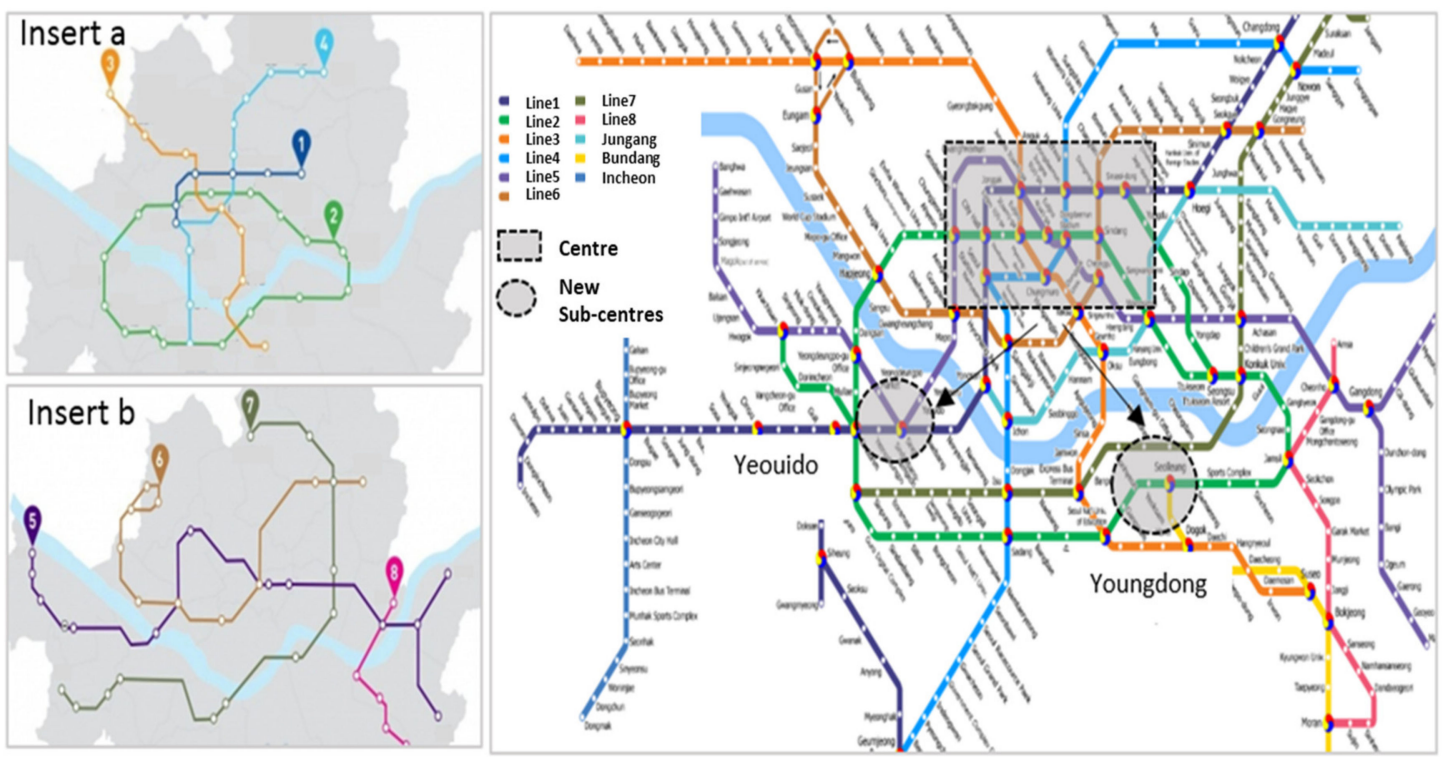

Figure 4. Subway maps for Seoul (Insert a: First Phase Subway Development; Insert b: Second Phase Subway Development) (source: adapted from Seoul Metro [80]).

\subsection{Key Interests Related to the Second Phase Subway Development at Multiple Levels}

Based on the analysis of documents and interviews, varying interests in the Second Phase can be identified at national, city, and neighbourhood scales and from transport and urban development perspectives. At the national level, the major interest in the Second Phase was supporting macro socio-economic goals in response to rapid urban development. As identified in the interviews with transport and spatial planners working at national and metropolitan levels, the top priority was to deal with the increasing demand for access to the economic hubs and the shift to a polycentric urban structure [58]. Improving the connectivity between Seoul and the newly-developed residential neighbourhoods in the peripheral areas was also a concern [53]. Furthermore, the project sought to create balanced spatial development across the metropolitan area.

Our research shows that, at the city scale, high-density mixed-development around the stations was promoted as a catalyst for development of local hubs according to a spatial hierarchy, from metropolitan to neighbourhood scale. Facilitating such local hubs was expected to contribute to a balanced and efficient spatial development of Seoul [81,82]. From a transport perspective, key goals were increasing accessibility between centres, and between centres and remote areas, as well as improving network functionality. At the local level, a key objective was to improve accessibility to jobs and opportunities, as well as to encourage commercial development in the immediate vicinity of the stations $[82,83]$. The development of local hubs around stations was promoted for enhancing the overall quality of living environment, especially in disadvantaged areas [56]. A summary of interests is presented in Table 3.

Table 3. Interests related to the outcomes of the Second Phase Subway Development at multiple levels.

\begin{tabular}{ccc}
\hline Level & Interests Related to Transport Development & Interests Related to Urban Development \\
\hline $\begin{array}{c}\text { National and } \\
\text { regional levels }\end{array}$ & $\begin{array}{c}\text { Deal with increasing demand for access to jobs } \\
\text { and services at a national/regional scale }\end{array}$ & $\begin{array}{c}\text { Increase competitiveness of Seoul and foster } \\
\text { balanced development of the metropolitan areas by } \\
\text { moving towards a polycentric urban structure }\end{array}$ \\
\hline City level & $\begin{array}{c}\text { Reduce congestion and improve accessibility to } \\
\text { the major centres from wider areas including new } \\
\text { towns, and connectivity between (sub)centres }\end{array}$ & $\begin{array}{c}\text { Trigger balanced and efficient development across } \\
\text { the city through high-density mixed-use projects and } \\
\text { facilitating local hubs around stations }\end{array}$ \\
\hline $\begin{array}{c}\text { Neighbourhood } \\
\text { level }\end{array}$ & $\begin{array}{c}\text { Improve local transport network and improve } \\
\text { accessibility to public transport and } \\
\text { pedestrian networks }\end{array}$ & $\begin{array}{c}\text { Develop local amenity and better infrastructure and } \\
\text { services around the stations }\end{array}$ \\
\hline
\end{tabular}




\subsection{Spatial Changes and Associated Long-Term Consequences at Macro and Micro Scales}

The Second Phase contributed to ongoing change in spatial structure from a monocentric to a polycentric metropolitan area, which was initially triggered by the First Phase of subway development $[53,58]$. Since the Second Phase started, commercial activity and employment density increased in proximity to the nodes (i.e., within $500 \mathrm{~m}$ radius of subway stations), primarily in the sub-centres, such as Yongdong [56,84] (Figure 5). Major nodes in the south, especially in Gangnam District, became major centres of development, especially because of additional public transport projects (e.g., a regional metro system), which were developed to connect these nodes, and these nodes with satellite cities further south. Some other local centres (i.e., those in the north of Seoul) gradually lost their functions $[84,85]$. Eventually, Yongdong took over many of the key economic and social functions [86]. In the peripheral areas, the enhanced access provided by the Second Phase partly contributed to the development of new towns.

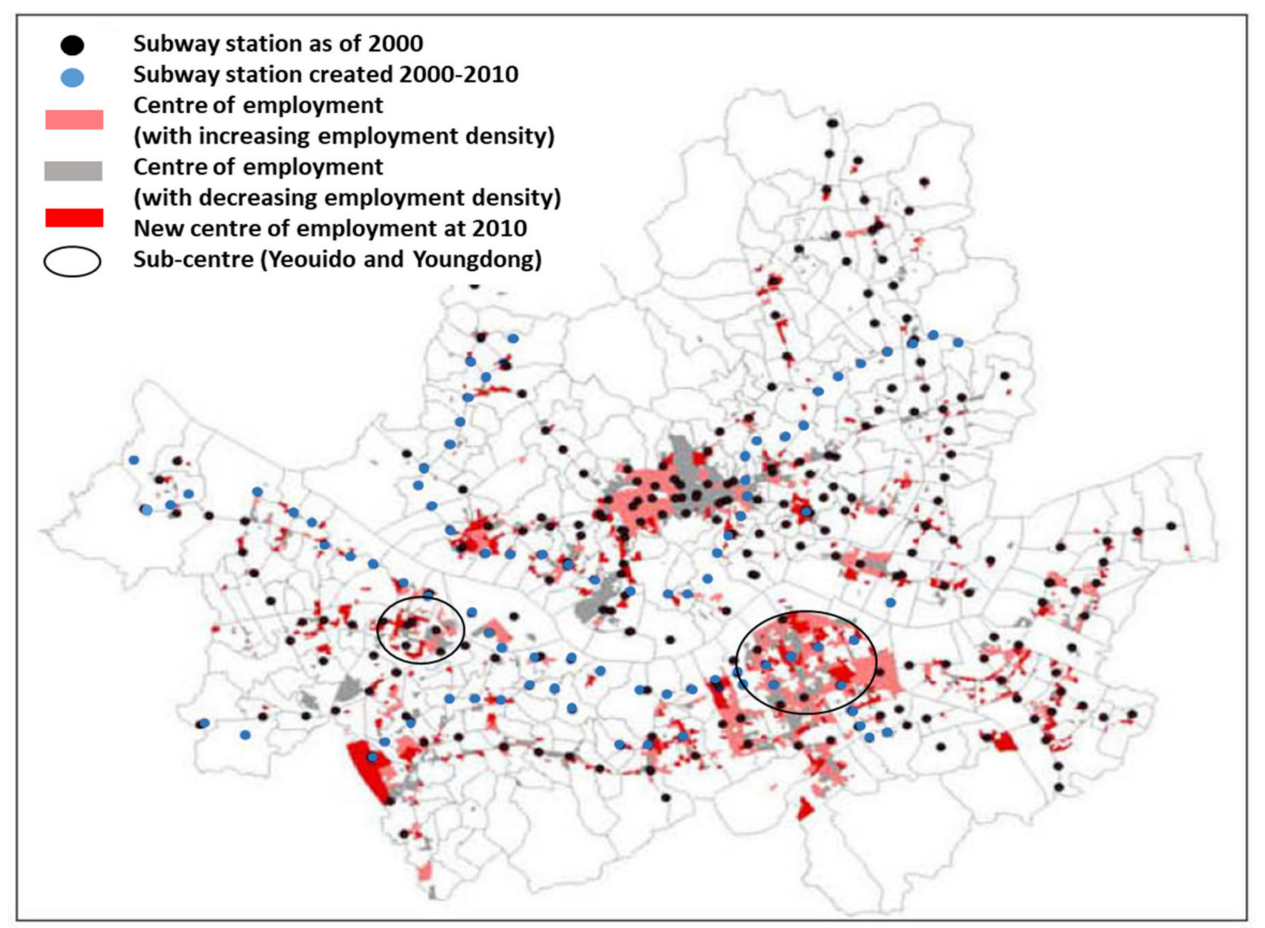

Figure 5. Change in employment density at centres of employment in Seoul from 2000 to 2010 (source: adapted from Jin and Jin [84]).

Our analysis illustrated that the Second Phase created varied levels and patterns of change in land use and the local environment along the transport corridors (i.e., the micro level). An empirical study [87] and our interviews with spatial planners showed that the development effects around stations varied between north and south, as well as between the commercial and residential centres. High-density (re)development around stations and along transport routes was noted mainly in the commercial centres of the south, while some in the north (Whangship-Li and Cheongrang-Li) were redeveloped to a moderate extent due to the low availability of vacant land and restrictive planning regulations [56]. Another issue is that, across Seoul, land near many stations has become dominated by residential development rather than by mixed-use development [56]. Massive housing-led regeneration projects have occurred in close proximity to stations, while the majority of local amenities were positioned along roads [87]. A limited extent of positive change in the local built environment adjacent to the stations was noted [88]. Public spaces and pedestrian paths near the stations were inadequate, especially in the north, and regeneration projects were often poorly integrated with the local environment around stations $[89,90]$. 
According to our analysis of documents and our interviews, the changes in the spatial structure of Seoul associated with the Second Phase contributed to the socio-economic development of the city at the macro scale. The centres of commerce and employment in Seoul, which were well connected to each other as well as to their wider areas, had a continuously-increasing role as a socio-economic hub. However, it was difficult to confirm whether the subway development actually increased access to opportunities for the whole urban society. Our research identified a growing percentage of the population who commuted by subway more than one hour [91-93]. Moreover, various studies [84,85] have indicated that different levels of job accessibility were observed in different parts of the city. Districts in the south (e.g., Gangnam District and Seocho District) have the highest level of job accessibility with the highest rates of increase, while north and east Seoul did not see much change since 2000.

Interviews with transport planners and a few studies on accessibility to public transport (e.g., $9589,90])$ indicated that there were limited consequences on quality of life at the local level, especially in local residential areas, due to the moderate level of station area development and poor connectivity between stations and the rest of the neighbourhoods (see also [56]). Station areas appeared to have played only a limited role as a socio-economic hub, given the dominance of residential projects as well as many of the local amenities located along roads [87,88]. Much of the population (except for those living in the sub-centres in the south) needed to travel to access services [94]. Some negative impacts of the housing-led regeneration projects were noted within the neighbourhood areas. Large-scale housing developments adjacent to stations often restricted mobility within the neighbourhoods, affecting the functionality of pedestrian pathways, and contributed to the loss of local identity [89,95]. We also identified that some local communities were displaced to make way for new housing developments in the vicinity of stations, although many of these developments were already planned, and were not strictly due to the subway expansion.

Our analysis revealed that there were spatially differential outcomes (e.g., accessibility to jobs and public transport) across the urban area, especially between the least and most deprived areas. In the districts with highest income (of households) [96,97], such as Gangnam, approximately $70 \%$ of residents commuted to work within one hour, while less than half of the residents in the areas of lowest income (e.g., Gangbuk District) could travel to work within one hour [92,93]. Such a difference was also seen with accessibility to public transport; the areas of highest income had much greater accessibility to public transport than the poorest areas. Almost half of Gangnam District had subway stations within a short walking distance (i.e., within $500 \mathrm{~m}$ ), while Gangbuk in the north has highest proportion of areas without a subway station within $500 \mathrm{~m}[98,99]$.

\subsection{Analysis of Issues Related to Social Outcomes from the Second Phase Subway Development}

Our study suggests that the Second Phase appeared to contribute to achieving the macro scale economic goals of the city. Within a short time period, the project increased connectivity to the major nodes from wider areas. However, it is not clear whether the Second Phase contributed to facilitating balanced development across the whole metropolitan area, even though this was a stated goal. In the centres, especially in the south, the positive impacts increased due to the iterative effect between development and the provision of transport infrastructure, while the peripheral areas experienced only limited positive impacts. The sub-centres in the south have seen an increasing concentration of jobs, while other sub-centres and local centres only had a limited amount of change around the nodes, especially in the peripheral areas. As a result, more people have to commute a longer time, especially those living in peripheral areas although subway lines have served a wider population.

The extent to which the respective interests at the local level were met by the outcomes of the Second Phase was less clear due to the limited level of spatial change around stations and the differential level of increase in accessibility between the centres and the rest of the city. Despite strong interest in spatial development around the stations, the subway development facilitated only a limited amount of high-density commercial development, especially in local centres in the peripheral areas, and the 
station areas only played a limited role as a local hub. The positive consequences on quality of daily life in local neighbourhoods were limited due to the inadequacy of the pedestrian pathways that connected to the stations, as well as the poor connectivity between subways and neighbourhoods, especially in the peripheral areas. Our research identified that the long-term spatial changes were closely related to multiple negative impacts on people living in low-income districts in the peripheral areas. They travelled further to access jobs and services, and were influenced by a lower quality of the living environment around the transport nodes. Overall, it is not clear whether the Second Phase has contributed to enhancing accessibility to opportunities for the whole urban population, or meeting the strong interests in obviating socio-economic disparity across the city.

Interviews with a principal transport planner and a project manager suggested that, because of the rapidly growing economy and population, the central government only focused on achieving immediate outcomes. Cost efficiency and increasing connectivity between principal nodes, and between the nodes and the new residential developments, were the main issues that were considered. Interviews with spatial planners indicated that developing station areas as a catalyst for the development of local hubs was little considered or discussed in the project planning process, despite being a stated goal of the official spatial plan $[80,81]$. Planners only considered station area development to a limited extent, and rarely took connectivity to public transport or the lack of pedestrian paths into consideration. Furthermore, meeting the differential needs of the different parts of the city (e.g., centres and peripheral areas) was hardly discussed, even though facilitating balanced development was a key policy goal.

\section{Discussion on Social Outcomes from Urban Transport Development}

The two exemplars of London and Seoul have illustrated that social outcomes from urban infrastructure development are produced in a complex manner, and are influenced by spatial changes and varied contexts. Our study showed that evaluating social outcomes from transport projects requires careful consideration of the consequences of multi-scale spatial changes over time, as well as of the varied interests in the project in the specific context of the city in question. In this section, we discuss the importance of understanding the interaction between transport and spatial development at macro and micro scales. We also discuss our insights related to how the social outcomes could be enhanced to better address the varied interests in urban transport development.

\subsection{Multi-Scale Spatial Development and Long-Term Consequences of Transport Development}

The two exemplars demonstrate the importance of understanding how spatial changes induced by urban transport infrastructure development at various scales influence the ultimate benefits for society that arise from such development. Our study revealed that benefits such as enhanced accessibility can be undermined by incremental spatial changes. In the case of the London, the JLE contributed to the success of a new economic centre (Canary Wharf) and to facilitating regeneration around the nodes, which resulted in enhanced accessibility to opportunities for many members of society. However, various negative consequences from spatial changes that were triggered by the regeneration projects detracted from the benefits of accessibility gains and enhanced living environments around stations. In the Seoul subway case, despite increased mobility at the macro level, the positive changes to quality of life were limited because of the low level of spatial change at many nodes (except for the commercial centres), and poor accessibility to jobs and services (concentrated in commercial centres) for most of the urban population.

Our study also indicated that expansion of transport networks does not guarantee increased access to opportunities for all because of the differential patterns and scales of the spatial changes occurring across cities. Both in Seoul and London, differential outcomes across urban areas can be attributed to the varied pace and scope of spatial development occurring over time in the different locations across each city, and among different social groups. In Seoul, the high-income districts in the commercial centre of the south benefited from enhanced accessibility that arose from increasing job density and improved transport networks. However, people in most other districts, especially 
those in the low-income peripheral areas, received only limited benefits and experienced multiple negative impacts, due to longer travelling time to jobs (which were being concentrated in the centres), limited development of local amenities, and little improvement in the built environment. In London, our study identified differential levels of benefits within and between neighbourhoods, and among different social groups. Such differences were closely related to the varied scales of the regeneration projects, as well as to varying accessibility to opportunities between the centre and peripheral areas, and between least and most deprived areas. Both cases also indicated that the long-term spatial changes created negative influences on social cohesion among local populations at city and local levels.

These results suggest that evaluating social outcomes requires investigating the interaction between transport and spatial development at macro and micro scales over time, and reflecting on how the consequences of such multi-scale interactions affect accessibility and the quality of life of local neighbourhoods across a city. Our research illustrated that the spatial changes occurring around transport nodes were incremental, and that the societal consequences of this cannot be fully foreseen when infrastructure development planning takes place. Therefore, to enhance the achievement of positive long-term social change in the future, rather than primarily focusing on enhancing ex-ante evaluation (see [100]), what is perhaps more needed is improving ex post evaluation, especially in relation to examining what actually happens from the spatial changes created. Such ex post evaluation needs to consider changes in the patterns and scale of land use around nodes, changes in the level of integration between stations and (re)developed local environments, changes in connectivity of the local road network, as well as connectivity to major destinations. Moreover, our study indicates that there needs to be explicit attention to the cumulative effects from the multi-scale spatial changes for specific populations and areas, especially those who experience multiple negative impacts [8]. Urban transport projects alone will not always bring about positive changes to the wellbeing of the whole society, nor facilitate a fair distribution of benefits across society $[9,14,101]$. The consequences of unbalanced spatial development across cities on the most and least deprived groups need to be evaluated and monitored to ensure that urban transport development bring desired outcomes across varied localities and social groups.

\subsection{Social Outcomes within Specific Contexts}

Our study illustrated that the social outcomes from urban infrastructure projects were related to the specific context of each case, such as the pattern and stage of urban spatial development and broader socio-economic contexts. These factors varied between Seoul and London, which created different issues that had to be addressed. In Seoul, the Second Phase resulted in only a limited level of spatial development around nodes and a limited role of the station areas as local hubs. Many interviewees emphasised that the linear pattern of urban development along roads resulted from the car-oriented, rapid urban development of Seoul, as well as from the restrictive planning regulations on land development at transport nodes. Conversely, in London, the JLE facilitated refurbishment of station areas and regeneration of the vicinity of stations, due to the rail-oriented urban (re)development (i.e., spatial development concentrated around nodes), as well as the availability of developable land around station areas.

These differences between the two exemplars imply that each case had different issues to deal with. In London, priority needed to be given to mitigating the various negative social consequences of the long-term spatial changes triggered by the (re)development of station areas. In Seoul, the key issue to enhance social outcomes appeared to be dealing with the increased commuting time for many local residents. Explicit attention is needed to consider how to trigger the appropriate spatial development at nodes in the peripheral areas of the city. Overall, our research clearly shows that an approach to enhance social outcomes should carefully address the huge diversity of local contexts that affect long-term consequences, and that such approach should be moving beyond panacea thinking [16]. 


\subsection{Implications for an Integrated Approach to Enhance Social Outcomes of Urban Infrastructure}

Our research suggests that discrepancies between transport planning and spatial development planning (see [47]) might result in limited benefits from urban infrastructure projects for society. These discrepancies may lead to a failure to deal with the long-term societal consequences arising from the multi-scale spatial changes. Our study indicates that, to ultimately enhance social outcomes, an integrated approach to transport and spatial development is needed [12,46], and that it should give attention to the scale and time dimensions of the spatial changes triggered by urban transport development projects.

The study findings suggest that a multi-level integrated approach needs to facilitate planning and evaluation of social outcomes, focusing on the long-term consequences of spatial changes on the quality of life of urban populations. A macro-level urban policy needs to address a broader range of goals of urban transport projects, as well as the social consequences that arise from unbalanced spatial development across cities. Such a policy needs to consider integration of spatial development and transport development at strategic locations (e.g., commercial centres in sub-centre and periphery), especially those with potential to become regional transit hubs. At the micro level, an area-based approach to planning and evaluation of projects, e.g., integrating infrastructure development into adjacent land uses and assessing the consequences of spatial changes on local environments, should be considered. In addition, there needs to be a tailor-made approach to integrated planning and evaluation that carefully addresses the interests and priorities of the local population in specific contexts, according to location (e.g., city centre, local centre, and regional centre), function (e.g., commercial and residential areas), socio-economic conditions (e.g., high-income and low-income areas), and the overall development stage of the city (e.g., rapidly expanding or renewing existing cities).

\section{Conclusions}

By examining urban transport development projects in megacities, London and Seoul, this paper investigated how the social outcomes from such projects play out by reflecting on the long-term spatial changes and on the varied interests in the outcomes of the projects at multiple levels. Our research clearly shows the need for an integrated and broader approach to urban transport infrastructure development that addresses social consequences of multi-scale spatial changes induced by projects, including those that are unexpected or unintended. Our research indicated that the expansion of urban transport networks by itself does not guarantee increased accessibility or quality of life for the whole of the society, due to the differential pace and scope of the spatial changes that occur across a city, as well as the unexpected or unintended negative impacts of spatial transformation at the local neighbourhood scale. The two case studies (London and Seoul) revealed that interactions between transport development and spatial development at multiple scales will cause unbalanced development across a city (e.g., concentrated commercial development in city centres) and negative consequences for neighbourhoods (e.g., physical severance and disparity around nodes). Such multi-scale consequences result in limited social outcomes from urban transport development-specifically, uneven distribution of accessibility and quality of life across local areas and groups.

We have established that the social outcomes are closely related to each specific context, such as the patterns of urban spatial development in a city. We argue that there is a need for a context-specific approach to evaluate outcomes and for adaptive management. In a city like London, which experienced spatial development occurring around the main nodes over a long period of time, attention needs to be given to the increasingly differentiated outcomes between nodes and the rest of their catchment areas. In rapidly growing cities, such as Seoul, which experienced high agglomeration effects in the $\mathrm{CBD}$, priorities for enhancing social outcomes should be: dealing with the limited spatial development around nodes in the peripheries; and reducing the disparity between the centre(s) and peripheries.

To ensure sustainable and equitable outcomes from urban transport projects, our research suggests that an integrated approach to transport and spatial development at multiple levels is essential. In developing a macro-level strategy for transport network development, urban policy makers and 
transport planners should consider a broader range of goals of urban transport projects, especially balanced development across the metropolitan area. At the local level, there needs to be an area-based approach to the planning (e.g., integrating infrastructure into land use) and to the evaluation of projects (e.g., ex post evaluation of the social impacts of spatial changes, including changes in local environmental quality and the functionality of local road networks). Such an integrated approach should carefully address the varying priorities of the various localities (e.g., city centre or local centre; commercial or residential areas) with their different socio-economic conditions. Overall, enhancing social outcomes requires careful consideration of the diversity of contextual circumstances that affects spatial changes and thus long-term consequences.

We recommend that to understand and enhance social outcomes at all scales, further examination of the contextual and institutional factors that affect the planning process and delivery of urban infrastructure development projects is required. For social outcomes to be the overarching objective of development projects, urban transport planning needs to be supported, not only by an integrated approach to transport and land-use planning, but also by appropriate institutional arrangements to support the delivery of integrated outcomes. Further research is needed to explore how specific institutional conditions (e.g., formal and informal rules) influence the way interests are identified and managed at multiple levels, so that, overall, social outcomes will be enhanced. Research about how planning rules might lead to different outcomes in different contexts will contribute to understanding the interrelations between local socio-economic conditions and resultant social outcomes. Moreover, by examining local stakeholder perspectives, in-depth investigation of the social consequences of spatial changes at varied localities will be of great value. Such research will enhance understanding of the social outcomes in different local contexts, such as those with varying levels of densification, gentrification, pedestrian traffic, and the socio-economic conditions of the neighbourhood.

Author Contributions: J.L.: content planning, literature search and review, data collection, data analysis, manuscript writing, and revising; J.A.: content planning and manuscript revising; F.V.: content planning and manuscript revising; J.W.: content planning and manuscript revising. All authors have read and agreed to the published version of the manuscript.

Funding: This research and APC has been funded by University of Groningen.

Acknowledgments: The authors would like to thank the various key informants and local residents who contributed their comments about the urban transport projects and their neighbourhoods. This work has been financially supported by University of Groningen.

Conflicts of Interest: There is no conflict of interest to declare.

\section{References}

1. ADB. Sustainable Urban Transport in Asia: Making the Vision a Reality Asian Development Bank: Manila, Philippines. 2006. Available online: https://www.adb.org/publications/sustainable-urban-transport-asiamakingvision-reality (accessed on 3 May 2018).

2. Dimitriou, H.; Ward, J.; Wright, P. Lessons for Mega Transport Project Developments and the Future of UK Cities and Regions 2015. Available online: https://assets.publishing.service.gov.uk/government/uploads/ system/uploads/attachment_data/file/499051/future-of-cities-mega-transport-projects.pdf (accessed on 18 February 2018).

3. ADBI. Infrastructure for Asian Connectivity; Asia Development Bank Institute: Manila, Philippines, 2017.

4. Beyazit, E. Evaluating social justice in transport: Lessons to be learned from the capability approach. Transp. Rev. 2010, 31, 117-134. [CrossRef]

5. Geurs, T.; Boon, W.; van Wee, B. Social impacts of transport: Literature review and the state of the practice of transport appraisal in the Netherlands and the United Kingdom. Trans. Rev. 2009, 29, 69-90. [CrossRef]

6. Stolp, A.; Groen, W.; van Vliet, J.; Vanclay, F. Citizen values assessment: Incorporating citizens' value judgements in environmental impact assessment. Impact Assess. Proj. Apprais. 2002, 20, 11-23. [CrossRef]

7. Rodrigue, J. The Geography of Transport Systems; Routledge: New York, NY, USA, 2017. 
8. Lee, J. Spatial ethics as an evaluation tool for the long-term impacts of mega urban projects: An application of spatial ethics multi-criteria assessment to Canning Town regeneration projects. Int. J. Sustain. Dev. Plan. 2018, 13, 541-555. [CrossRef]

9. Levinson, D. Identifying winners and losers in transportation. Transp. Res. Rec. J. Transp. Res. Board. 2002, 1812, 179-185. [CrossRef]

10. Brenner, N. The urban question: Reflections on Henri Lefebvre, urban theory and the politics of scale. Int. J. Urban Reg. Res. 2000, 24, 361-378. [CrossRef]

11. Graham, S.; Marvin, S. Splintering Urbanism: Networked Infrastructures, Technological Motilities and the Urban Condition; Routledge: London, UK, 2001.

12. Bertolini, L. Integrating mobility and urban development agendas: A manifesto. Disp Plan. Rev. 2012, 48, 16-26. [CrossRef]

13. Wegener, M.; Fürst, F. Land-Use Transport Interaction: State of the Art; IRPUD: Dortmund, Germany, 1999.

14. Martens, K. Justice in transport as justice in accessibility: Applying Walzer's 'Spheres of Justice' to the transport sector. Transportation 2012, 39, 1035-1053. [CrossRef]

15. Jones, P.; Lucas, K. The social consequences of transport decision-making: Clarifying concepts, synthesising knowledge and assessing implications. J. Trans. Geogr. 2012, 21, 4-16. [CrossRef]

16. Healey, P. Collaborative planning in perspective. Plan. Theory 2003, 2, 101-123. [CrossRef]

17. Switzer, A.; Bertolini, L.; Grin, J. Transitions of mobility systems in urban regions: A heuristic framework. J. Envion. Policy Plan. 2013, 15, 141-160. [CrossRef]

18. Flyvbjerg, B. Case Study. In The Sage Handbook of Qualitative Research, 4th ed.; Denzien, N., Lincoln, Y., Eds.; Sage: Thousand Oaks, CA, USA, 2011; pp. 301-316.

19. IUS. Global Power City Index 2018; The Mori Memorial Foundation: Tokyo, Japan, 2018.

20. UN-HABITAT. Planning Sustainable Cities: Global Report on Human Settlements; UN-HABITAT: Nairobi, Kenya, 2009.

21. Bhatta, B. Analysis of Urban Growth and Sprawl from Remote Sensing Data; Springer: Berlin, Germany, 2010.

22. Castells, M. The Rise of Network Society; Wiley: Hoboken, NJ, USA, 2010.

23. Pflieger, G.; Rozenblat, C. Urban networks and network theory: The city as the connector of multiple networks. Urban Stud. 2010, 47, 2723-2735. [CrossRef]

24. Zanon, B. Infrastructure network development, re-territorialisation process and multilevel territorial governance: A case study in northern Italy. Plan. Pract. Res. 2011, 26, 325-347. [CrossRef]

25. Geurs, T.; van Wee, B. Accessibility evaluation of land-use and transport strategies: Review and research directions. J. Trans. Geogr. 2004, 12, 127-140. [CrossRef]

26. Vecchio, G.; Porreca, R.; Rivera, D. Socio-spatial concerns in urban mobility planning: Insights from competing policies in Quito. Sustainability 2020, 12, 2923. [CrossRef]

27. Hall, P.; Pain, K. The Polycentric Metropolis; Earthscan: London, UK, 2006.

28. Bertolini, L.; Curtis, C.; Renne, J. Station area projects in Europe and beyond: Towards transit-oriented development? Built Envion. 2012, 38, 31-50. [CrossRef]

29. Gospodini, A. Urban development, redevelopment and regeneration encouraged by transport infrastructure projects: The case study of 12 European cities. Eur. Plan. Stud. 2005, 13, 108-111. [CrossRef]

30. Vanclay, F. Conceptualising social impacts. Envion. Impact Assess. Rev. 2002, 22, 183-211. [CrossRef]

31. Cervero, R. Transport infrastructure and global competitiveness: Balancing mobility and livability. Ann. Am. Acad. Political Soc. Sci. 2009, 626, 210-225. [CrossRef]

32. Hall, P. Cities of Tomorrow: An Intellectual History of Urban Planning and Design in the Twentieth Century; Blackwell: Oxford, UK, 2002.

33. Pereira, R.; Schwanen, T.; Banister, D. Distributive justice and equity in transportation. Transp. Rev. 2017, 37, 170-191. [CrossRef]

34. Lucas, K.; van Wee, B.; Maat, K. A method to evaluate equitable accessibility: Combining ethical theory and accessibility-based approaches. Transportation 2016, 43, 473-490. [CrossRef]

35. Revington, N. Gentrification, transit and land use: Moving beyond neoclassical theory. Geogr. Compass 2015, 9, 152-163. [CrossRef]

36. Ong, P.; Miller, D. Accessible Cities and Regions: A Framework for Sustainable Transport and Urbanism in the 21st Century; UC Berkely Centre for Future Urban Transport: Berkely, CA, USA, 2005.

37. Hall, P. Great Planning Disasters; Penguin: Berkeley, CA, USA, 1980. 
38. Marsden, G.; May, D. Do institutional arrangement make a difference to transport policy and implementation? Lesson for Britain. Envion. Plan. C Gov. Policy. 2006, 24, 771-789. [CrossRef]

39. Healey, P. In search of the 'strategic' in spatial strategy making. Plan. Theory Pract. 2009, 10, 439-457. [CrossRef]

40. Heeres, N.; Tillema, T.; Arts, J. Integration in Dutch planning of motorways: From 'line' towards 'area-oriented' approaches. Transp. Policy 2012, 24, 148-158. [CrossRef]

41. Giddens, A. Time, space and regionalization. In Social Relations and Spatial Structures; Gregory, D., Urry, J., Eds.; Macmillan: London, UK, 1985; pp. 265-295.

42. Madanipour, A. Design of Urban Space: An Inquiry into a Social-Spatial Process; Wiley: Chichester, UK, 1996.

43. Priemus, H.; Flyvbjerg, B.; van Wee, B. Decision-Making on Mega-Projects: Cost-Benefit Analysis, Planning and Innovation; Edward Elgar Publishing: Cheltenham, UK, 2008.

44. Baker, M.; Hinks., S. Infrastructure delivery and spatial planning: The case of English local development frameworks. Town Plan. Rev. 2009, 80, 173-199. [CrossRef]

45. Fainstein, S. Mega-projects in New York, London and Amsterdam. Int. J. Urban Reg. Res. 2008, 32, 768-785. [CrossRef]

46. Straatemeier, T.; Bertolini, L. Joint accessibility design: Framework developed with practitioners to integrate land use and transport planning in the Netherlands. J. Transp. Res. Board. 2008, 77, 1-8. [CrossRef]

47. Legacy, C.; Curtis, C.; Sturup, S. Is there a good governance model for the delivery of contemporary transport policy and practice? An examination of Melbourne and Perth. Transp. Policy. 2012, 19, 8-16. [CrossRef]

48. Te Brommelstroet, M.; Bertolini, L. Integrating land use and transport knowledge in strategy-making. Transportation 2010, 37, 85-104. [CrossRef]

49. Miller, D.; Patassini, D. Beyond Benefit Cost Analysis: Accounting for Non-Market Values in Planning Evaluation; Ashgate: Aldershot, UK, 2005.

50. Rydin, Y. Governing for Sustainable Urban Development; Earthscan: London, UK, 2010.

51. Hoekveld, G.; Needham, B. Planning practice between ethics and the power games: Making and applying an ethical code for planning agencies. Int. J. Urban Reg. Res. 2013, 37, 1638-1653. [CrossRef]

52. OMEGA Centre. Project Profile UK Jubilee Line Extension; OMEGA Centre: London, UK, 2011.

53. SMG. 30 Year History of Subway Development of Seoul; Seoul Metropolitan Government: Seoul, Korea, 2003.

54. SMG. Sync Seoul; Seoul Metropolitan Government: Seoul, Korea, 2015.

55. TfL. Travel in London; Report 6. 2013. Available online: http://content.tfl.gov.uk/travel-in-london-report-6. pdf (accessed on 1 November 2018).

56. Choi, J.; Gu, J.; Lee, S.; Kim, T.; Seung, H. History, current issues, and perspectives of station area development of Seoul. J. Korea Plan. Assoc. 2012, 376, 3-19.

57. Hall, P.; Hickman, R. Moving the city East: Explorations into contextual public transport-orientated. Dev. Plan. Pract. Res. 2008, 23, 323-339.

58. Kim, K.; Suh, Y. The impacts of city comprehensive plans on the urban spatial structure of Seoul since 1960s: Focused on the implementation of 'the Multi-Centric City Concept'. J. Urban Des. Ins. Korea Urban Des. 2016, 17, 5-23.

59. Vanclay, F. The potential application of qualitative evaluation methods in European regional development: Reflections on the use of Performance Story Reporting in Australian natural resource management. Reg. Studies. 2015, 49, 1326-1339. [CrossRef]

60. Hoch, C. Evaluating plans pragmatically. Plan. Theory 2002, 1, 53-75. [CrossRef]

61. Hennink, M.; Hutter, I.; Bailey, A. Qualitative Research Methods; Sage: London, UK, 2010.

62. Vanclay, F.; Baines, J.; Taylor, C.N. Principles for ethical research involving humans: Ethical professional practice in impact assessment Part I. Impact Assess. Proj. Apprais. 2013, 31, 243-253. [CrossRef]

63. ONS. Indices of Deprivation in 2015. Available online: http://dclgapps.communities.gov.uk/imd/idmap.html (accessed on 1 December 2018).

64. Hamnett, C. Unequal City: London in the Global Arena; Routledge: London, UK, 2004.

65. London-tube.com. London Tubemap-A new angle on the London Underground. Available online: http://www.london-tubemap.com/ (accessed on 4 December 2018).

66. Willis, J. Extending the Jubilee Line: The Planning Story; London Transport: London, UK, 1997.

67. Pharoah, T. Jubilee Line Extension Development Impact Study; University of Westminster: London, UK, 2003. 
68. GLA. Economic Evidence Base for London 2016. Available online: https://www.london.gov.uk/whatwe-do/research-and-analysis/economic-analysis/economic-evidence-base-london-2016 (accessed on 30 November 2018).

69. MHCLG. Land Use by Borough and Ward 2005. Available online: https://data.london.gov.uk/dataset/ (accessed on 28 October 2018).

70. MHCLG. Land Use by Borough and Ward 2011. Available online: https://data.london.gov.uk/dataset/ (accessed on 28 October 2018).

71. Mitchell, B. Jubilee Line Extension: From Concept to Completion; ICE Publishing: London, UK, 2003.

72. JLEISU. Working Paper No. 54 Summary Final Report; Jubilee Line Extension Impact Study Unit, University of Westminster: London, UK, 2004.

73. Mboumoua, I. Revisiting the growth coalition concept to analyse the success of the Crossrail London megaproject. Eur. Plan. Stud. 2017, 25, 314-331. [CrossRef]

74. CABE. Stratford Station 2009. Available online: http://www.cabe.org.uk/case-studies/stratford-station (accessed on 15 November 2018).

75. TfL. WebCAT 2019. Available online: https://fl.gov.uk/info-for/urban-planning-and-construction/planningwith-webcat (accessed on 1 February 2019).

76. ONS. LSOA Atlas 2015. Available online: https://data.london.gov.uk/dataset/lsoa-atlas (accessed on 1 February 2019).

77. TfL. WebCAT 2014. Available online: https:/tfl.gov.uk/info-for/urban-planning-and-construction/planningwith-webcat/ (accessed on 7 June 2018).

78. KOTI. History of Subway Development of Korea; Ministry of Land and Infrastructure: Seoul, Korea, 2012.

79. Lee, K. History of Transport Policy of Seoul; Seoul Development Institute: Seoul, Korea, 2017.

80. Seoul Metro. Subway Map. Available online: http://www.seoulmetro.co.kr $/ \mathrm{kr} /$ index.do?device=PC (accessed on 8 August 2018).

81. SMG. Seoul Plan for 2000s; Seoul Metropolitan Government: Seoul, Korea, 1990.

82. SMG. Seoul Development Plan; Seoul Metropolitan Government: Seoul, Korea, 1997.

83. OGD. 1995 District Plan; Office of Gangnam District: Seoul, Korea, 1995.

84. Jin, J.; Jin, E. The effects of changes in subway system and job accessibility on changes in employment density of employment centers in Seoul. J. Korea Plan. Assoc. 2015, 50, 111-130. [CrossRef]

85. Lee, J.; Kim, I. Polycentric City Development of Seoul to Become a Megacity; Seoul Institute: Seoul, Korea, 2009.

86. Maeng, D. Change in Spatial Structure of Seoul; Seoul Development Institute: Seoul, Korea, 2010.

87. Lim, H.; Kim, Y. Investigation of mixed nature of urban spatial structure of station areas in Seoul. J. Envion. Stud. 2011, 50, 47-61.

88. Lim, H. Developing Transit-Supportive Neighbourhood Model in Seoul Development; Seoul Development Institute: Seoul, Korea, 2007.

89. Go, J. Improving Accessibility to Public Transportation Through the Analysis of Subway Structure of Seoul; Seoul Institute: Seoul, Korea, 2008.

90. Lee, C.; Lee, K.; Chung, S. Role of Transportation Planning for Urban Regeneration Projects in Seoul; Seoul Institute: Seoul, Korea, 2015.

91. KOSIS. Percentage of Population Who Travelled by Subway more than One Hour to Work by District. 2000. Available online: http://kosis.kr/index/index.do (accessed on 30 November 2018).

92. KOSIS. Percentage of Population Who Travelled by Subway more than One Hour to Work by District. 2010. Available online: http://kosis.kr/index/index.do (accessed on 30 November 2018).

93. KOSIS. Percentage of Population Who Travelled by Subway more than One Hour to Work by District. 2015. Available online: http://kosis.kr/index/index.do (accessed on 30 November 2018).

94. Jeong, I.1.; Lee, B.; Kim, H. Improving Fairness of Infrastructure Development Policy for the Fair Society; Korea Research Institute of Human Settlement: Anyang, Korea, 2011.

95. Chang, N.; Kim, S.; Lee, H. Key Issues of Urban Regeneration of Seoul; Seoul Institute: Seoul, Korea, 2007.

96. SRDS. Household Incomes of Seoul 2008. Available online: http://data.si.re.kr (accessed on 30 November 2018).

97. SRDS. Household Incomes of Seoul 2011. Available online: http://data.si.re.kr (accessed on 30 November 2018).

98. KRA. Map of Public Transport Accessibility. Available online: http://www.korass.or.kr/ (accessed on 7 August 2018). 
99. Lee, W.; Na, Y.; Park, S.; Lee, B.; Cho, C. Transportation equity analysis based on the metropolitan household survey. J. Korean Urban Geogr. Assoc. 2012, 15, 75-86.

100. Van Wee, B. How suitable is CBA for the ex-ante evaluation of transport projects and policies? A discussion from the perspective of ethics. Transp. Policy. 2012, 19, 1-7. [CrossRef]

101. Adli, S.; Chowdhury, S.; Shiftan, Y. Justice in public transport systems: A comparative study of Auckland, Brisbane, Perth and Vancouver. Cities 2019, 90, 88-89. [CrossRef]

(C) 2020 by the authors. Licensee MDPI, Basel, Switzerland. This article is an open access article distributed under the terms and conditions of the Creative Commons Attribution (CC BY) license (http://creativecommons.org/licenses/by/4.0/). 